\title{
THE SOMITES OF THE CHICK
}

\author{
LEONARD W. WILLIAMS \\ From the Harvard Medical School, Boston
}

NINETEEN FIGURES

The first consistent account of the history of the somites of the chick, in which was presented the much discussed theory of the resegmentation of the vertebral column, was published by Remak in 1855. He believed that the somites are originally hollow cubical masses of cells which, as the medullary groove deepens, become triangular prisms with dorsal, medial, ventral and end walls. The medial ventral edge of each somite elongates and, reaching the notochord, divides into two leaf-like processes which, uniting with those of the opposite side, grow around the notochord and form the tissue of the perichordal sheath or Wirbelkörpersäule. From the same edge, he believed, there grows into the carity of the somite a mass of cells, the core Urwirbelkern, which greatly reduces the cavity. The core of the somite soon fuses with the neighboring walls with the exception of the dorsal wall. Each somite is now divided into an epithelial or epithelioid upper wall and a mesenchymal mass formed by the fusion of the core and walls of the somite. Remak named the former the Rückentafel or Muskelplatte. The latter, the sclerotome, he named the Wirbelkernmasse. There soon appears a contrast between the anterior and posterior parts of the sclerotome. The spinal nerve with its ganglion and roots appears in the anterior portion of the sclerotome from which Remak believed that it arose. The posterior part becomes condensed forming what Remak and others have called the vertebral arch. The correctness of this interpretation will be discussed later. Remak believed that toward the end of the fourth day this vertebral arch is pushed backward so that its posterior edge is covered by the dorsal lamella or Rücken- 
lafel of the following somite, to which it becomes attached. Since each arch retains its connection with the dorsal lamella of its own somite, it is now attached to the dorsal lamellae of two adjacent somites. There now forms in the perichordal sheath at the center of each segment, a conspicuous condensation which is separated from the condensations of the adjacent segments by light transverse zones, which Remak believed were clefts. These condensations, however, do not correspond with the vertebral centra and, to distinguish them from the latter, Remak called them the primitive vertebral centra.

During the fifth and sixth days, a striking change occurs in the perichordal sheath. This consists in the apparent resegmentation, Neue Gliederung, of this sheath, by which the definitive vertebral centra are formed. Since the primitive centra arise from the whole medial ventral edge of the somite, and the vertebral arch comes from the posterior part of each somite, the arch is consequently attached to the posterior part of the primitive centrum. The spinal nerve and ganglion occupy a space between two vertebral arches which corresponds with the anterior part of the primitive centrum. However, in a later stage the relation between these structures is reversed: the arch is now attached to the anterior end of the centrum and the ganglion lies in a space which corresponds with the posterior end of the centrum. This change in the position of the nerve in relation to the vertebral arch is the basis of Remak's assertion that there is a resegmentation of the vertebral centra, or more accurately of the perichordal sheath (Wirbelkörpersäule.) It will be remembered that Remak worked with whole or dissected embryos, consequently it is not surprising that he mistook the primary perichordal condensations which form the intervertebral ligaments for the vertebral centra. This error was corrected by Gegenbaur ('62) who, while accepting Remak's theory as a whole, introduced certain modifications. Unfortunately, conceiving the sclerotome or Wirbelkernmasse to be identical with the primitive vertebral centrum of Remak or the intervertebral condensation, Gegenbaur introduced some confusion which is scarcely yet cleared away, but he rightly maintained that the apparent spaces which separate successive midsegmental 
or intervertebral condensations are really masses of loose tissue which become the vertebral centra. Gegenbaur also saw that in birds and reptiles (as is also true in mammals) the tissue around the notochord forms a membranous, "skeletogenous" or "perichordal" sheath which is replaced by a cartilaginous or precartilaginous sheath, which Minot named the chondrostyle. Resegmentation is effected by the formation of joints in the chondrostyle.

In 1868 His published a new account of the somites of the chick. He found that each somite is primarily a flat quadrangular body consisting of a core and cortex; the former is a small cluster of irregular rounded cells; the latter is composed of fusiform radiating cells attached to one another only at base. Each cell bears peripherally a free projecting process. The more posterior somites differ in several respects from the anterior or first formed somites. They are cubical, or nearly so, their walls have more epithelial characters, and their cores are larger. His like Remak believed that in the chick the dorsal lamella is entirely converted into voluntary muscle, and Bardeen maintains that this is also true in the pig; nevertheless, this view has not been generally accepted. The credit of showing that the spinal ganglia arise from the neural crest, not from the sclerotome, belongs to His but he failed to see that the sympathetic ganglia arise in the same manner. He believed wrongly that the core of the somite forms the sympathetic ganglion and that the ventral wall of the somite forms only the muscular coat of the aorta. All connective tissues, according to his now abandoned parablast theory, arise from the extraembryonic mesoderm and migrate along the blood vessels into the spaces between the entoderm, ectoderm, neural tube, notochord, and somites. Consequently His believed that Remak's theory of resegmentation of the vertebral column was wholly without foundation. Goette, however, in 1875 pointed out that the tissues of the vertebral column really do arise from the sclerotomes.

Froriep ('83) found in each segment a lyre-shaped mass of dense mesenchyma, which Bardeen has recently named the seleromere. This extends from a midsegmental point below the 
notochord laterally, dorsally and backward to the following intersegmental fissure. Its central portion (the primitive vertebral centrum of Remak) soon encircles the notochord and then differentiates into a fibrous ring, surrounding the notochord, and a transverse bar of cartilage. The former becomes the intervertebral disc, or takes part in the formation of the intervertebral joint; the latter, the intercentrum or subnotochordal bar (hypochordale Spange) usually degenerates without first losing its connection with the lateral parts of the scleromere, but in connection with the first two cervical vertebrae it persists, forming the body of the atlas and a part of that of the axis. The vertebral centrum, arising in the loose tissue between the midsegmental condensations, fuses, Froriep believed, with the preceding scleromere, forming in this way the definitive vertebra. The centrum of the atlas, however, does not fuse with the preceding but with the succeeding scleromere, that of the axis. The only criticism I have of Froriep's work is the one made in a former paper, namely, that the scleromere which ultimately gives rise to the intervertebral disc (or ligament), the intercentrum, the neural arches, the ribs, and the myoseptum, cannot be regarded as a morphological unit. The only actual units with which we are here concerned are the centrum, the neural arches, the ribs, and the intercentrum. Froriep's description of these and of their relation to the definitive vertebrae is correct.

Remak's theory received new support from Von Ebner ('88) whose discovery of a midsegmental diverticulum of the cavity of the somite, which divides the sclerotome into essentially equal anterior and posterior parts, reopened the whole question of vertebral formation. Von Ebner found this fissure, which he named the intervertebral fissure, in the lizard, chick, mouse, and bat. Schultze ('96) claimed that in birds the fissure arises independently of the cavity of the segment and forms a connection with it later, but in mammals is entirely without connection with it. I have pointed out elsewhere that there is really no fissure in mammals and the same is true, I find, in birds. Von Ebner, like Gegenbaur, thought that the sclerotome is the structure which Remak called the primary vertebral centrum; consequently the fissure 
seemed to him to be the only evidence needed to prove the correctness of Remak's theory. The anterior half of one sclerotome he believed fuses with the posterior half of the preceding sclerotome to form an intersegmental vertebra.

This view was attacked by Corning ('97) who pointed out the weakness of Von Ebner's position. He maintained rightly that a midsegmental vertebral centrum does not exist and that the sclerotome is not the primitive vertebral centrum of Remak. This criticism elicited a reply from Von Ebner ('92) which contained the fundamental truth that the dense mass of tissue forming the greater portion of the posterior part of the sclerotome is a composite structure. The "primitive arches," i.e., the lateral portions of the scleromeres, are merely segmental structures which contain the anlagen of several diverse structures.

A very different conception of the structure of the vertebral column is that of Goette who in a series of papers, particularly one in 1896 , presents the theory that each segment contains primarily the anlagen of one haemal and two neural arches, an intercentrum, and a centrum. In the tail of a well advanced embryo of Lacerta, there is a gradual transition in the structure of the neural arch. Anteriorly each half of the arch is a broad plate of bone; in the middle of the tail it is divided by a deep vertical groove, or by a narrow slit, into a large anterior and a small posterior arm; and still farther back it is represented by two bars of bone, of which the anterior is the larger. In adult lizards, however, the neural arch of every caudal vertebra is an undivided broad plate. The transverse processes of the caudal vertebrae of Lacerta, and also of certain mammals, show a similar tendency to divide into anterior and posterior portions. The dense tissue in the middle of each segment represents the intercentrum and the loose tissue between every two intercentra and between the right and left intersegmental arteries forms the primary centrum. The bases of the neural arches broaden and fuse with the primary centrum, forming the secondary centrum. The haemal arch extends from below the intercentrum backward and downward into the intermyotomic septum. It may fuse with the posterior end of the preceding vertebra, as it does in Lacerta, or with the anterior 
end of the following centrum. Goette believes that these elements, namely the centrum, the intercentrum, the two pairs of neural and the single pair of haemal arches, unite with one another in several ways with the abortion or enlargement of certain units so as to form the various types of vertebrae occurring in Digitates and in the Amiidae among fishes.

Männer ('99) found two pairs of cartilaginous neural arches in Angius and Lacerta; and Schauinsland ('00) discovered two pairs of cartilaginous neural arches in the caudal region of embryos of Hatteria. In embryos which were about to hatch, he found conditions similar to those described by Goette in Lacerta. However, in Hatteria not only are the neural arches and transverse processes double, but the centrum also shows indications of the same structure because, as Schauinsland believes, it arises from parts of the sclerotomes of two adjacent segments. Goette, however, does not maintain that the centrum is double, but that, corresponding to each segment, there are two axial elements, - the centrum, which is intersegmental, and the intercentrum, which is midsegmental in position. Schauinsland regards the subnotochordal bar (hypochordale Spange) of Froriep as the haemal arch.

After Remak had shown that the Urwirbel or protovertebra contains anlagen of the body musculature as well as of the vertebrae, the name became inappropriate; nevertheless, it was used without question until Goette in 1875 proposed to use the term segment. A few years later in the second edition of Foster and Balfour's "Textbook of Embryology" ('83) the term mesoblastic somite, or somite, was used as a substitute for the name protovertebra. It seems best to denote by the word somite one of the blocks of mesoderm formed by the segmentation of the vertebral or somitic plate and to make the segment include a pair of somites with the corresponding nephrotomes.

While Von Ebner was discussing the intervertebral fissure and resegmentation, Rabl ('88), demonstrated that the dorsal lamella or muscle plate of Remak becomes a two-layered plate, the Hautmuskelplatte (dermomyotome) and that the inner layer only, the Muskellamelle (myotome) forms muscle, whereas its outer layer. 
the Cutislamelle (dermatome) is converted into the connective tissue of the dermis. At the same time Hatschek proposed to call Remak's Wirbelkernmasse the sclerotome.

In the same year Paterson ('88) discovered that the ventral edges of the dermomyotomes of the trunk of the chick grow downward into the membrana reuniens inferior and so supply the musculature of the abdominal and thoracic walls, but that the musculature of the limbs does not arise directly from the dermomyotomes. Paterson saw that the dermomyotome is composed of two lamellae but did not discover that the outer lamella contributes to the dermis.

Kaestner ('90) upon insufficient grounds attacked the work of Rabl and Paterson. He believed that some of the cells of the cutis plate become myoblasts and that the remainder form an epithelium which is destroyed during the third day by parablastic tissue. He further maintained that the Muskelknospen, or growing ventral edges of the dermomyotomes, described first by Paterson, contribute directly to the musculature of the limbs.

Kollmann ('91) describing the somites of human embryos, asserted that whereas the muscle plate, or inner layer of the dermomyotome, supplies the dorsal musculature of the trunk, the cutis plate gives rise to the ventral body musculature and to that of the limbs. He admitted, however, that dermal connective tissue arises from the myotomes (dermomyotomes?) of the trunk.

Fischel ('95) took a somewhat intermediate position between Rabl and Paterson on the one hand and Kaestner andKollmann on the other. He pictured the growing dorsal and ventral edges of the dermomyotome in the chick and showed that the prebrachial dermomyotomes do not have ventral growing edges. The ventral buds or growing edges of the dermomyotomes of the trunk, he thought, break up into lonse tissue which mingles with the mesenchyma of the nephrotome and lateral plate. The museles of the limbs and of the ventral part of the body wall arise in the mass of tissue formed in this way, and Fischel judges from analogy that these muscle masses probably arise from the dermomyotome. 
Engert ('00) in the chick and Bardeen and Lewis ('01) in human embryos, proved beyond reasonable doubt that Rabl and Paterson were in the right and that the ventral body musculature does arise from the ventral part of the myotome or muscle lamella but that the muscles of the limbs arise independently of the myotome. Fingert shows that all of the cutis plate except its extreme upper and lower edges forms dermal mesenchyma and that these edges become transformed en masse into myoblasts forming the much thickened dorsal and ventral edges of the myotome. Bardeen ('00) however, maintained, I believe wrongly, that the cutis plate in the pig gives rise only to myoblasts.

My intention, when I began this paper, was to study the later development of the notochord of the chick and the relation of the notochord to the vertebrae, as a continuation of the work upon the notochord published in 1907. I soon found, however, that more knowledge of the structure and development of the somites was necessary. I have therefore followed with great care the history of one of the two somites of the second segment up to the time of its transformation into the sclerotome, myotome, and dermatome. The differences at the time of their origin between the second and several other segments have been pointed out. A brief account of the history of the tenth segment, and of the relation of its sclerotomes to the vertebrae is given, and finally the history of the twenty-fifth and forty-fourth segments is described, in order to emphasize the differences, most of which are well known, between the occipital, cervical, trunk, and caudal segments.

\section{THE SECOND SOMITE}

Rabl (89) in his extensive work upon the early history of the mesoderm has shown that, shortly before the origin of the first segment, the mesoderm of the chick is represented by a sheet of syncytial tissue which extends in all directions from the primitive streak. Centrally it is thick and contains numerous closely packed but irregularly arranged nuclei. Peripherally it gradually becomes thinner until, near the inner edge of the area vasculosa, 
it is an exceedingly thin and imperfect sheet, composed of small irregular clusters of stellate cells or cell-like masses of protoplasm. The portion of the mesoderm in front of the primitive streak, which Rabl names the gastral mesoderm, is bisected by the notochord. Small isolated cavities appear in the larger clusters of cells of the antero-lateral portion of the gastral mesoderm and, gradually enlarging, unite with one another, forming on either side the parietal or amnio-cardiac cavity. The portion of the gastral mesoderm below the medullary plate and beside the notochord is thicker than its lateral part, and the first intersegmental cleft appears in this thick medial edge at a point nearly midway between the anterior extremity of the embryo and the primitive streak. This cleft, as is well known, is somewhat V-shaped, being prolonged on each side of the median line laterally and slightly backward. Patterson ('07) and Miss Hubbard ('08) have proven experimentally that this cleft is the most anterior of the entire series and not, as Von Baer thought, the third from the head. It forms the posterior boundary of the first segment, which, being continuous anteriorly with the unsegmented mesoderm of the head, is incomplete. Each somite of this segment produces approximately half as much muscle and mesenchyma as the following somites. A second intersegmental fissure appears quickly and cuts off the first pair of complete somites, those of the second segment. Each somite of this segment (fig. 1) is a very irregular flattened mass of cytoplasm containing many nuclei, which are rounded or oval and are without definite arrangement. There is observable, however, a very faint indication of a division of the somite into upper and lower layers.

While the third intersegmental fissure is forming, there appears a longitudinal constriction which lies parallel to, and a short distance from the notochord, and divides the gastral mesoderm into a narrow medial zone, the somitic plate, and a broad lateral region, the lateral plate. This constriction extends forward so as to form the lateral boundary of the first and second somites and also extends backward some distance behind the third intersegmental cleft. The somitic plate, like all other portions of the mesodermal sheet, gradually becomes thicker toward the primitive streak. 
In embryos of three segments, the second somite (fig. 2) is quadrangular and is considerably thicker than before. It is now distinctly divided into upper and lower layers, which are continuous with one another at the edges of the somite. The longest axes of the oval nuclei radiate from the center of the somite. Its surface is still very irregular.

New somites are constantly forming, and each differs more or less from the others, as will be seen in figs. 10 to 14 , which represent transverse sections of several newly formed somites. It seems wisest, therefore, to study the development of the somites of a single segment, the second, and then to compare these with the others.

In embryos of six segments (fig. 3) the edges of the medullary plate are considerably elevated above the second segment and each of the somites of this segment has become an irregular triangular prism with dorso-medial, dorso-lateral, lower, and anterior and posterior surfaces. The first two of these arisefrom the upper surface of the earlier somite. The dorso-medial or medial surface is concave and is molded against the convex lower surface of the medullary plate. The dorso-lateral (which will soon become the upper) surface is quite irregular. The lower surface is convex. The medial edge of the somite is almost in contact with the notochord and its anterior end is prolonged forward so that the anterior end or wall of the somite slopes from above downward and forward. The somite now contains a flattened core consisting of a few rounded nuclei and a small amount of cytoplasm.

The coelom expands rapidly and has now divided the greater part of the lateral plate into an upper or parietal and a lower or visceral layer. It appears also in the thicker medial edge of the lateral plate, forming a slight expansion $(C)$ and finally sends a small tortuous prolongation through the constricted area or stalk which connects the second somite and the lateral plate. Thus a small prolongation of the coelom enters the somite and separates the dorsal wall of the somite from the core. It is now clear that each somite of the second segment for a time has no central cavity and is without a core. This fact was overlooked by Remak who believed that each newly formed somite has a central cavity, and by His who states that from the first the somite has a core. 
His states that the most anterior somites do not contain cavities, but there are cavities in the first three or four somites and the communications between them and the coelom in embryos of from ten to twenty segments were discovered by Dexter ('91). This cavity and communication appear in the second somite of embryos of five or six segments. Bonnet shows that the first four somites of sheep embryos have a similar structure and connection with the coelom.

In embryos of nine segments, the neural tube is closed in the region of the second segment and consequently the shape of each of the second somites (fig. 4) is somewhat altered. Its medial surface is nearly vertical, the upper surface is larger and is nearly horizontal, and the lower surface is marked by a groove for the aorta, which has now appeared and is rapidly enlarging. The cortex or wall of the somite, particularly the dorsal wall, has a very remarkable structure which has been recognized, I believe, only by Held ${ }^{1}$ whose figures show this structure very beautifully and accurately. While having the appearance of a simple or stratified columnar epithelium, the cortex is really an epithelioid syncytium of unusual character. The oval or elliptical nuclei are imbedded in columns of cytoplasm which proximally, i.e., toward the core, are continued into a dense basal layer of cytoplasm and distally end in irregular sparingly branched processes. Certain of these distal processes unite so as to form a faint external boundary of the cortex, but others extend freely into the space between the somite and the ectoderm and other adjacent structures. Nuclei preparing to divide withdraw to the basal layer of cytoplasm, leaving conspicuous gaps in the outer part of the wall. I have been unable to find a single mitotic figure elsewhere in the somitic cortex than in close proximity to the basal layer, and it is interesting to note that practically all of the axes of the mitotic figures are parallel to the surfaces of the cortex. Thestructure described is quite unmistakable in the first five or six somites which have relatively few cells, but posteriorly it is somewhat obscured by the much greater number of cells in the cortex.

2 Figures 91-96 of birds, $98-99$ of the rabbit.

The American Journat or Anatomy, Vor, 11. No. 1. 
I believe, however, that the cortex of all the somites of the chick and, probably, of all birds and mammals, is an epithelioid syncytium of this peculiar type.

The upper wall of the somite is thin laterally where it is continuous with the upper layer of the lateral plate. Medially it gradually becomes thicker, its medial edge being nearly twice as thick as its lateral edge. The medial wall of the somite immediately underlying the thick edge of the upper wall is quite thin and is indented by a small groove-like evagination of the cavity of the somite, (fig. 4,G.U.), for which I propose the name upper myotomic groove. The appearance of this groove is the first indication of the formation of the myotome. The cells at its base apparently change from a cylindrical to an oval or spherical form in preparation for their subsequent longitudinal elongation as they become definitely recognizable myoblasts. The floor and the lower part of the medial and anterior walls have fused with the core of the somite to form a mass of mesenchyma, the sclerotome, or since it subsequently receives a very considerable addition from other parts of the cortex, the primary sclerotome. The fusion between the core and cortex begins first at the anterior end of the ventro-medial edge of the somite and, owing partly to the expansion which accompanies the transformation of the tissue of the somite into mesenchyma, this angle grows forward and medially more rapidly than the remainder of this edge of the somite.

In embryos of twelve segments, a second groove appears (fig. 5, G.L.) in the medial wall of the second somite. This, however, is an invagination of the wall and lies at a slightly lower level than the upper myotomic groove. Since it marks the lower edge of the muscle plate, I propose to call it the lower myotomic groove.

The upper myotomic groove, I believe, has never been described or figured. It is, however, neither as constant nor as conspicuous as the lower groove which, although often figured, has not been described or named. A cord of vascular cells partly fills the lower myotomic groove.

The myotome is represented by a narrow zone between the two myotomic grooves which differs considerably from the 
adjacent portions of the cortex of the somite. The cells or celllike elements of the myotome are shorter and are more closely packed than those of the rest of the cortex. Moreover, the cells of the myotome radiate from the upper myotomic groove, upward, dorso-medially, medially, and ventro-medially. The upper wall of the somite is somewhat thicker and its cells are more closely placed than before. Its medial portion is overlaid by a plate of neural crest cells.

The communication between the coelom and the cavity of the somite is larger than in younger embryos and is approximately circular in cross section, i.e., as seen in sagittal series. It has now reached perhaps its greatest development. The stalk of the segment is deeply constricted both on its upper and its lower surface, in front and behind the communication.

The sclerotome is slightly larger, owing partly to the transformation of more of the anterior and medial walls of the somite into mesenchyma. The posterior wall and the posterior ventral edge of the somite are still epithelioid and have not contributed to the formation of the sclerotome. The amount of expansion of the sclerotome is shown in the model (text fig. 1) and can be indicated precisely by the example of the second somite of an embryo of thirteen somites whose sclerotome in sagittal section is longer by nearly one-fourth than the dorsal wall, and is one-tenth longer than the distance between the centers of the adjacent intersegmental clefts. The aorta divides the lower part of the sclerotome into two keel-shaped processes, the aortic or lateral (fig. 5, P.A.), which projects downward and medially between the aorta and the pharynx, and the notochordal or medial process (fig. 5, P.N.), which, projecting toward the notochord, separates the aorta from the neural tube. Fig. 119 (p. 204) in Minot's "Human Embryology" shows that there is a similar projection forward of the lower part of the sclerotome of the rabbit.

In embryos of fifteen segments (fig. 6) the most conspicuous alteration of the second somite as compared with that of embryos of twelve segments, is the deepening of the lower myotomic groove and its extension upon the anterior and, to a slight extent, upon the posterior surface of the somite. The groove is deep and nar- 
row anteriorly but is broad and shallow posteriorly. The muscle plate underlies the medial fourth or fifth of the upper wall of the somite and its nuclei are gradually becoming elongated in the longitudinal plane, instead of as before in the transverse plane. The boundaries of the cells of the muscle plate are indistinct but are probably present.

The further description of this somite requires a study of the adjacent blood-vessels which have been best described by Evans. His figure ('09, 2, fig. 3b) of the blood-vessels of the head of an embryo of fifteen segments shows that the anterior cardinal vein consists of three portions, namely, a long slender vessel, lying at the side of the neural tube and between it and the unsegmented mesoderm of the head, the vena capitis medialis; a short transverse portion, which I find lies between the first and second somites; and finally an irregular trunk which passes obliquely laterally and backward upon the upper surface of the parietal plate to a point opposite the third somite, where it opens into the common cardinal vein or duct of Cuvier. The latter is a minute vertical vessel which passes through the lateral plate in the mesocardium laterale (Koelliker) and joins the vitelline vein. The first indication of the anterior cardinal vein is seen in an embryo of six segments (H.E.C. no. 639). The aortae are just established but are still small and irregular vessels. Each aorta, however, gives off into the first intersegmental eleft a branch of nearly its own size which extends dorso-medially to the side of the neural tube: The aorta and its branches are connected with a delicate cellular network which extends between the somites, between them and the neural tube, and between the medial portion of the parietal plate and the ectoderm. The cells of this network can often be distinguished from the ordinary mesenchymal cells by slight differences in the intensity of the stain. They are shown by their connection with the aorta and by their subsequent history to be vascular cells. Two strands of these vascular cells are of particular and immediate interest; one of these extends from the aorta upward through the second intersegmental fissure where it connects with the second strand which extends from the termination of the aortic branch in the first fissure, forward between the neural 
tube and the unsegmented mesoderm of the head and backward between the former and the somites. Both of these strands are quickly replaced by blood-vessels; the former in an embryo of eight segments (H. E. C. no. 642) is transformed into the first intersegmental artery; and the latter forms the posterior end of the vena capitis medialis and, behind the first intersegmental cleft, the beginning of a chain of anastomoses between the distal ends of the intersegmental arteries. An apparently isolated vessel represents the beginning of the third or oblique portion of the anterior cardinal vein.

In an embryo of fourteen segments, each aorta bears a dorsolateral branch in the first intersegmental cleft. One of these is connected with a small and somewhat tortuous transverse vessel which, joining the posterior end of the vena capitis medialis and the anterior end of the oblique portion of the anterior cardinal vein, forms the transverse portion of the latter vessel. On the other side of the embryo, the posterior end of the vena capitis medialis and the distal end of the dorso-lateral branch of the aorta are bound together only by strands of vascular cells. Similar dorso-lateral branches of the aorta occur in the second intersegmental cleft and are connected with the intersegmental arteries by transverse vessels.

The anterior cardinal veins of two embryos of fifteen segments in the Harvard embryological collection (nos. 1444 and 1460) are in the main like those of the embryo of the same number of segments figured and described by Evans. The transverse portion of this vein in both embryos is connected with the aorta by a quite direct vessel or in one case by two vessels. Both embryos are probably younger than the one studied by Evans for in one (no. 1460) the common cardinal veins are not present, and in the other they are very minute. The second intersegmental cleft on each side contains a single T-shaped branch of the aorta which is apparently formed by the fusion of the preceding vessels. One arm of the $\mathrm{T}$ anastomoses with the posterior prolongation of the vena capitis medialis, the other extends upward between the stalks of the second and third somites and then expands in an irregular flattened vessel which, uniting by minute anastomoses with simi- 
lar vessels in the adjacent intersegmental clefts and with irregular vessels upon the parietal plate, forms the oblique or third portion of the anterior cardinal vein.

The posterior part of the anterior cardinal vein is formed, as Evans has shown to be the case with certain other veins, from several separate branches of the aorta. The first intersegmental artery gives rise to the posterior part of the vena capitis medialis, leaving that of the second intersegmental fissure to serve as the first definitive intersegmental artery.

The dorsal wall of the second somite of embryos of fifteen segments is almost separated from the lateral plate by the enlargement of the vessels of the network which gives rise to the oblique portion of the anterior cardinal vein. A very narrow bridge, however, connects the dorsal wall of the somite and the parietal plate and forms the roof of the much reduced communication between the cavity of the segment and the coelom.

The floor and the lower part of the walls of the somite fuse with its core and are quickly converted into sclerotomic tissue. The upper part of the walls of the somite, however, has a different history, for instead of fusing with the sclerotome this part of the cortex of the somite forms a center of growth from which much of the mesenchyma not only of the sclerotome but also of the dermis proliferates. Moreover, in addition to mesenchyma this part of the somite also produces the myotome. It is important, therefore, to distinguish the roof of the somite, with its bordering zone of growth, from the sclerotome, and for this purpose Remak's name Rückentafel and its English equivalent, dorsal lamella, will serve.

The lower or lateral edge of the myotome merges gradually with the sclerotome at the bottom of the lower myotomic groove, but I cannot find a center of growth here, nor can I determine whether or not there is a migration of cells to or from the myotome.

The plate of neural crest cells is migrating laterally and now overlies the adjacent edges of the somite and parietal plate.

In embryos of eighteen segments (fig. 7) one sees a continuation of the several processes described above, namely, the deepening of the lower myotomic groove and its further extension upon the 
ends of the somite, the enlargement of the third part of the anterior cardinal vein and the resulting separation of the dorsal lamella and the parietal plate, the migration laterally of the neural crest cells and the proliferation from the edges of the dorsal lamella of cells which contribute to the growth of the myotome and sclerotome. The lower myotomic groove, which is now scarcely more than a cleft, and the myotome underlie the medial half of the dorsal lamella and consequently the sclerotome is connected with the dorsal lamella only by a stalk whose diameter is somewhat less than half the length of the somite.

The sclerotome of this segment now begins to fuse with the adjacent sclerotomes, and in all later embryos it is impossible to distinguish the boundaries of the sclerotomes of the first five or six segments. It is important, therefore, to note the relation of the sclerotome to surrounding structures. Dorsally it is bounded by the dorsal lamella. Laterally it is attached to the somatic or parietal and the splanchnic or visceral layers of the lateral plate. Medially it is in contact with the neural tube and the notochord. Its ventral surface is in contact with the aorta and bears the notochordal and aortic processes which come into contact with the entoderm on each side of the aorta. The dorsal part of the anterior surface of the sclerotome is in contact with the transverse portion of the anterior cardinal vein, its ventral part slopes forward and downward so that the notochordal process (Text-fig. 1.) projects forward beyond the plane of the upper part of the intersegmental fissure, one third the length of the somite. The posterior surface of the sclerotome inclines sharply forward and downward so as to allow the notochordal process of the following sclerotome to project forward under the second somite.

The capillary vessels between the sclerotomes and between them and the neural tube have begun to sink into the sclerotomes, and thus the sclerotomic tissue receives its first blood-vessels.

In embryos of twenty-five segments the dorsal lamella (fig. 8) inclines downward laterally at an angle of about $45^{\circ}$ with the median plane. The myotome has extended laterally so as to unite with the greater part of the turned under lateral edge of the 
dorsal lamella. A small stalk of mesenchyma still binds the sclerotome to the essentially complete dermomyotome and prevents the final fusion of the edges of the myotome and cutis plate or dermatome. The nuclei of the lower part of the myotome are distinctly larger than those of its upper or medial edge. Mitoses are abundant in all parts of the myotome.

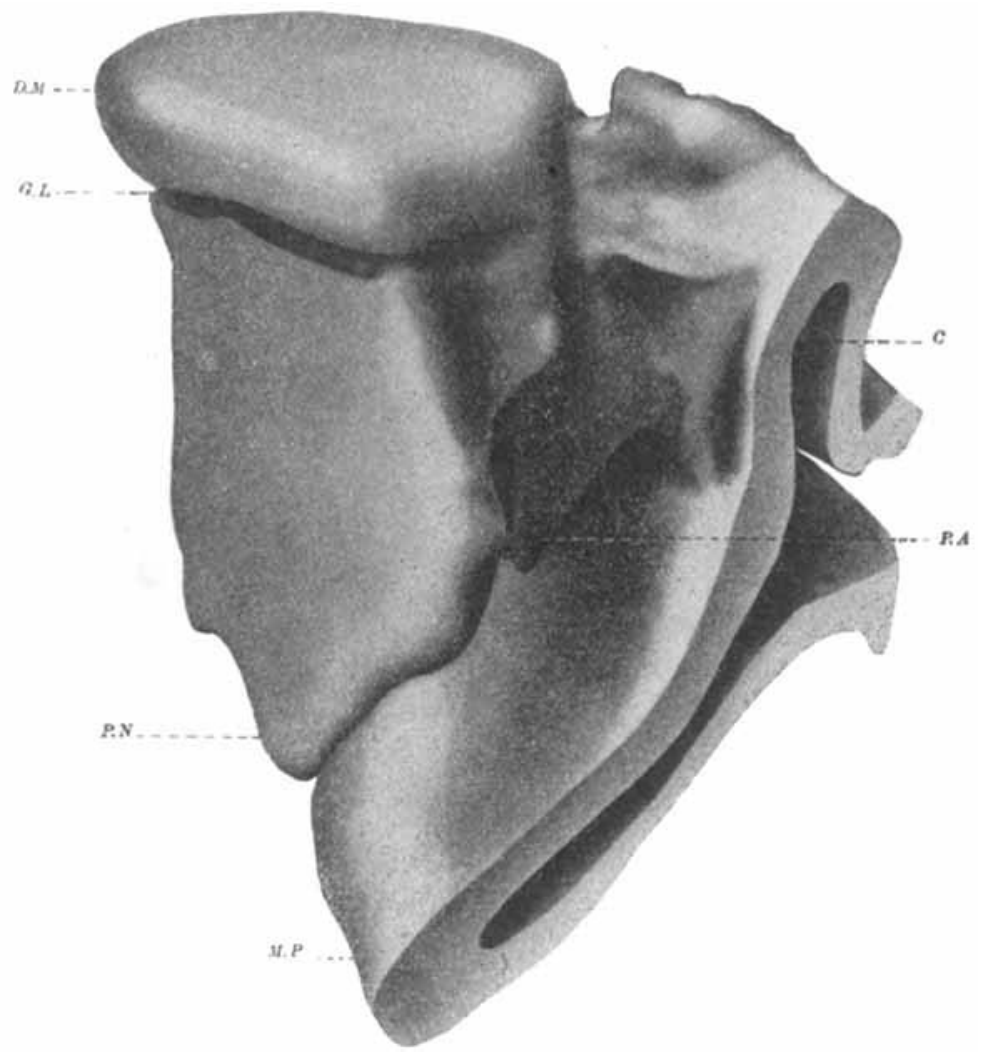

Text fig. 1. Model of the left somite of the second segments of an embryo of eighteen segments. The medial, anterior and part of the dorsal surface are seen. $\times 400$. H. E. C. no. 1466.

The dermomyotome is barely complete when its disintegration begins. This process, however, is only slightly indicated at this time in a small area just lateral to the center of the cutis plate. 
As Rabl and others have shown, the cells of this area begin to separate slightly and to send out free distal protoplasmic processes toward the ectoderm. At the same time, I find that a few cells not in mitosis withdraw to the basal layer of cytoplasm which as before is separated from the muscle plate by a cleft, the remains of the cavity of the somite.

The third portion of the anterior cardinal vein (fig. 8, C.A.) is still farther from the ectoderm and is now separated from the aorta only by a rather thin sheet of mesenchyma. It extends outward only to the level of the upper surface of the muscle plate, and it is separated from the ectoderm by the lower edge of the dermal plate and, ventrally, by a part of the mass of neural crest cells which is forming the ganglion of the vagus. The lateral, anterior, and posterior boundaries of the somite and later of the cutis plate, are indicated by a small acute ridge (fig. $8, R$.) upon the inner surface of the ectoderm. This ridge now marks the boundary between the cutis plate (fig. $8, D$ ) and the neural crest cells (N.C.) A few isolated neural crest cells can be seen migrating laterally from the roof of the neural tube.

Evans states that "The center of each sclerotome is, on its upper surface, supplied by a sheet of closely anastomosed capillaries; but the outer divisions of the sclerotome are not so supplied. There capillaries are absent for a considerable time, so that the vertebral column presents a succession of vascular and non-vascular zones, the former areas in each case overlying the segmental vessels" ('09, 2, p. 515). This statement does not hold good for the sclerotomes of the four cephalic segments owing doubtless to the fact that the cephalic sclerotomes differ considerably in structure (compare p. 77) from the spinal sclerotomes. The sclerotomic mesenchyma of the head is divided into a vascular outer and upper zone above the aorta and lateral to the intersegmental arteries and a non-vascular zone lying beneath the neural tube and the notochord. Evans' figure (cf. '09, 1, fig. 3) shows that the richest capillary plexus lies in a longitudinal zone at the side of the neural tube and between it and the medial or dorso-medial surface of the sclerotomes. The capillaries of this plexus, like other capillaries around the sclerotomes, begin to sink into, or to 
be surrounded by, the sclerotomic tissue when the embryo has about twenty segments, and in embryos of twenty-five segments they are quite surrounded by sclerotomic tissue.

The notochordal processes of the sclerotomes now unite beneath the notochord, separating it and the neural tube from the entoderm, and also unite beneath the aorta with the aortic processes, separating the aorta of each side from the entoderm.

In embryos of forly segments (fig. 9) the dermomyotome is much larger than before and is now of irregular thickness, being more than twice as thick at the junction of its middle and lower thirds as in its upper fourth. This is due to the rapid expansion of the tissue of the cutis plate which accompanies its transformation from an epithelioid into a reticular or mesenchymal form. This transformation can be readily followed in transverse or frontal sections, for, beginning at a point somewhat lateral to the center of the cutis plate, the area of disintegration rapidly spreads in all directions until it reaches the lower, anterior, and posterior edges of the cutis plate. The history of the lower edge of the cutis plate is brief, for, as Fischel has shown, the dermomyotome of each of the prebrachial somites does not develop along its lateral or lower edge a zone of growth; consequently this edge is quickly transformed into mesenchyma. The zones of growth along the anterior and posterior edges of the dermomyotome continue for some time to produce streams of cells which augment the mass of mesenchyma, between the ectoderm and the myotome. The cells arising from the two centers of growth on the posterior edge of one and on the anterior edge of the following myotome form a dense mass of mesenchyma which in frontal sections is very conspicuous.

The upper part (approximately one-fourth) of the cutis plate retains an epithelioid aspect as is well shown in figure 121 in Minot's "Human Embryology." It is differentiated, however, into a loose distal portion and a thin dense basal layer containing both dividing and resting nuclei. The latter layer forms the outer boundary of the cavity of the segment which is now reduced to a narrow cleft in the upper edge of the dermomyotome. I have not been able to follow in detail the further history of the upper 
edge of the lateral layer of the dermomyotome of this somite, but it seems to be converted into myoblasts like the upper and lower edges of the lateral layers of the dermomyotomes of the trunk.

The myotome has a clavicular form in vertical section, its upper edge being slightly bent toward the neural tube and its lower edge being strongly inclined laterally. The rapid expansion of the mesenchyma arising from the cutis plate has apparently caused the overlying ectoderm to bulge outward. The inner surface of the myotome is quite sharp and regular and is only loosely attached to the sclerotomic tissue. The outer surface, on the contrary, is closely connected with the overlying mesenchyma and is somewhat irregular, owing to the formation of large irregular spaces. These are most abundant somewhat below the center of the plate, and appear to indicate the beginning of the separation of the myoblasts to allow the interpolation of connective tissue elements. Maurer's figure ('04, fig. 24) of the dorsal edge of one of the dermomyotomes of the middle of the trunk of a chick embryo of five days differs in certain respects from sections of this and of all other dermomyotomes of the chick that I have seen. The outer surface of the muscle plate is represented as regular and well defined, not the inner surface; the medial or inner surface is irregular, owing to the migration of sclerotomic tissue into the muscle plate. Finally, the upper edge of the dermomyotome is very thin and acute, while in all the segments that I have seen it is thick and rounded. I cannot explain the wide divergence between Maurer's observations and my own.

The lower edge of the muscle plate is not well defined but merges gradually with the adjacent connective tissue. It is slightly indicated, however, by a blood-vessel which passes close under it to supply the mesenchyma of the dermatome and which anastomoses with other vessels that pass between the slightly divergent lower ends of the adjacent myotomes.

The nuclei of the lower part of the myotome, as before, are larger and less closely packed than those of its upper part. The majority of them are elongated longitudinally, but a few, particularly those near the middle of the inner surface of the plate, are rounded or are elongated in another direction. Similarly the axes of the 
vast majority of mitotic figures are longitudinal, but, as will be seen in the figure, a few are transverse or are directed otherwise than longitudinally. Bardeen ('00) maintained against the general opinion that the mesenchyma between the myotome and the ectoderm, in the pig at least, does not arise from the cutis plate whose cells migrate in a mass and without losing their epithelial arrangement, from the middle of the anterior border of the myotome, backward, upward, and downward toward the corresponding edges of the myotome where the cutis plate cells turn over the edge of the muscle plate and, with the exception of a few which degenerate, become myoblasts. The proof of this migration lies in the gradual reduction in the size of the cutis plate; in the gradual transition in structure between the muscle plate and the cutis plate; and finally in the existence of an external membrane upon the periphery of the cutis plate. Nevertheless, there is no doubt that the cutis plate in the chick gives rise to the mass of mesenchyma in question, for not only can the gradual transformation of the epithelioid cutis plate into mesenchyma be followed, but there is also no path open by which this tissue can migrate from the parietal plate. The ganglion of the vagus and the anterior cardinal vein quite fill up the narrow slit between the lower edge of the muscle plate and the ectoderm through which alone the tissue could migrate. In the majority of the segments of the chick, a flat wedge-shaped plate of mesenchyme projects upward between the lower part of the cutis plate and the ectoderm, just as is the case in mammals; but in these segments the structure and history of the cutis plate is the same as in the second segment, except that the cutis plate has many more cells, and there is every reason to believe that it produces mesenchyma. I have not had an opportunity to follow the development of the cutis plate in any mammal with sufficient care to warrant a positive assertion, nevertheless, the similarity in structure and development of the cutis plate in birds and mammals leads me to doubt Bardeen's conclusions.

The sclerotome of this somite has fused completely with the adjacent sclerotomes, but its anterior boundary is indicated by the first intersegmental vein and its posterior boundary by the first 
definitive intersegmental artery and the second vein. Occasionally a small artery occurs on one or both sides in the place of the normally aborted first intersegmental artery. The outer part of the sclerotome is somewhat denser than its medial portion.

The four occipital segments have only rudiments of spinal ganglia, but the ganglionic commissure of the vagus extends backward through the somites of each side to the aborting ganglia of the fifth and sixth segments. No ventral nerve root forms in the first segment but, as Chiarugi has shown, the hypoglossal nerve has three roots belonging respectively to the second, third, and fourth segments.

Frontal sections of the myotome show that its upper and lower edges differ considerably in form. Its upper part, in an embryo of forty-four segments (H. E. C. no. 98) is of nearly uniform thickness and at each end narrows sharply to an acute edge which is separated by a narrow hyaline zone from the next myotome. The middle of the myotome is thicker than its upper part and is symmetrically convex. Its anterior, and to a less degree its posterior edge are obliquely truncated so that an acute wedge of sclerotomic tissue projects between the ends of the adjacent myotomes. The inner surface of the lower part of the myotome is more convex than its outer surface, and wedges of sclerotomic tissue, apparently the rudiments of the myosepta, separate this part of the myotome from the adjacent myotomes.

Transverse sections through the middle of the last formed somite of embryos of two, five, ten, fifteen, twenty-five, thirty, and forty-four segments are represented in figures 1 and 10 to 15 . The somites of the different regions of the body show certain differences which, though not large, have not been sufficiently emphasized, for it is assumed that all somites have the same structure and history. Certain investigators upon this assumption have tried to bridge over gaps in the development of a particular segment by taking the structure of a more anterior or more posterior one as a later or an earlier stage of development. Lillie, for example, says (p. 185): "The manner of origin of these parts (of the somite) can be studied fully in an embryo of twenty-five or thirty somites, by comparing the most posterior somites in which 
the process is beginning with somites of intermediate or anterior positions in the series which show successively later stages." Kollmann expresses the same idea more specifically (p. 43 and 44):2 "A myotome from the posterior part of the trunk will be represented because its condition immediately follows that of the myotome of the embryo of two weeks, which is not the case with the myotomes of the anterior part of the trunk. There, in correspondence with the more advanced development of the anterior part of the body, the myotomes are considerablymoreadvanced than those of the posterior part of the trunk. One can therefore make out various stages of development of this muscle organ in a single embryo."

Our attention is at once arrested by the great variation in the size of the somites. There is, from in front backward to the thirtieth, a gradual increase in the size of the somites; beyond this, that is, in the caudal region, the somites gradually become smaller. The fifth somite is apparently an exception for it is nearly as large as the fifteenth.

A distinct core appears first in the ninth or tenth somite and each succeeding somite as far back as the thirtieth or thirty-fifth segment has a larger core. The greater size of the more posterior somites is due largely to the fact that the somitic plate from which they are formed is thicker posteriorly. The structures of the anterior part of the embryo grow more rapidly than those of its posterior part and consequently each somite is always larger than those behind it. In other words, the anterior somites, which at the start are smaller and more primitive than the posterior somites, because of their more rapid growth always keep in advance of the latter. Thus we see that the second somite (fig. 5) of an embryo of twelve segments is larger, as well asmore advanced, than the fif-

2" Es soll hier zunächst ein Myotom aus dem hinteren Rumpfabschnitt dieses Embryo geschildert werden, weil sich dessen Verhalten unmittelbar an dasjenige des zwei Wochen alten Embryo ansehliesst, was mit den Myotomen im Vorderrumpf nicht der Fall ist. Dort sind sie in Uebereinstimmung mit der ganzen vorgeschrittenen Ausbildung des Vorderkörpers beträchtlich denen des Hinterrumpfes voraus. Man kann also verschiedene Entwickelungsstufen dieses Muskelorganes kennen lernen an einem und dernselben Embryo." 
teenth somite of a slightly older embryo (fig. 12). The growth of the segments is shown in the longitudinal sections as well as in the transverse sections, as will be seen from the following table of measurements.

\begin{tabular}{c|c|c|c|c}
\hline \multirow{2}{*}{$\begin{array}{c}\text { NUMBER OF } \\
\text { SERGMENTS OF } \\
\text { EMBRYO }\end{array}$} & \multicolumn{3}{|c}{ LENGTH IN Microns } \\
\cline { 2 - 2 } & Second somite & Fifth somite & Tenth somite & Fffteenth somite \\
\cline { 2 - 2 } 2 & 71 & & & \\
3 & 78 & & & \\
4 & 93 & & & \\
5 & 93 & 93 & & \\
7 & 99 & 96 & & \\
8 & 109 & 99 & & \\
9 & 87 & 93 & & \\
9 & 99 & 87 & & \\
10 & 109 & 96 & 68 & \\
10 & 93 & 93 & 68 & \\
11 & 99 & 99 & 74 & \\
12 & 78 & 99 & 68 & \\
13 & 99 & 93 & 71 & \\
15 & 99 & 96 & 68 & \\
15 & 93 & 93 & 74 & \\
17 & 99 & 93 & 78 & \\
17 & 68 & 90 & 68 & \\
19 & 99 & 93 & 84 & \\
& & & & \\
\hline
\end{tabular}

In embryos of thirty segments, all of the somites are from 139 to 156 microns long.

Furthermore the later somites do not recapitulate the development of the earlier somites; on the contrary, they merely omit the initial phases of the development of the earlier somites. Thus the core gradually forms in the second somite whereas that of the tenth and later somites is present from the first. In the same way the upper myotomic groove appears in the second somite after the formation of the ninth segment, but in the twenty-fifth and thirtieth somites it appears almost at once. So also the nephrotome is in a more advanced stage of development in the newly formed posterior segments than in the anterior segments at the time of their origin. 
It is not my purpose to follow in detail the development of each segment, but merely to mention the most conspicuous points of difference, most of which are already known, between the somites of the head, neck, trunk, and tail, and to determine as far as possible the relation of the somite to the sclerotome and of the sclerotome to the vertebra.

\section{THE TENTH SOMITE}

The tenth somite will serve as a type of the somites of the neck, just as the second has served as an example of an occipital segment. The structure of this somite at the time of its origin (fig. 10) needs no description, except to note that the intersegmental fissures which bound it are inclined slightly forward below.

While the three following segments are forming, the tenth somite of each side grows considerably and, owing apparently to the pressure of the surrounding structures, becomes somewhat pentagonal, with nearly equal dorsal, medial, and ventro-lateral surfaces and smaller lateral and ventro-medial surfaces. The single important structural change is the thinning out of the medial and anterior walls and the formation at the top of the former of the upper myotomic groove.

An extensive fusion of the core with the antero-ventral angle of the floor of the tenth somite is present in embryos of fifteen segments and in embryos of seventeen and eighteen segments the lower myotomic groove appears on both the medial and the anterior walls of the somite. The newly formed notochordal process now replaces the ventro-medial surface of the somite and the ridge between the dorsal and lateral surfaces has disappeared. Consequently the somite is now triangular. A mesenchymal mass, the aortic process, projects downward between each aorta and the corresponding posterior cardinal vein, but it apparently arises entirely from the nephrotome, not from the sclerotome. The anterior end of the notochordal process projects some distance forward and consequently the medial portion of the intersegmental fissure is inclined forward ventrally so as to enclose 
with the ectoderm of the dorsal surface of the embryo an angle of $76 .^{\circ}$ This part of the sclerotome is thus carried forward one-third or one-fourth the length of the somite. The succeding intersegmental fissures are more and more vertical, the fifteenth being the first that is without any inclination forward. The sclerotomes of the first fifteen somites, except the first which, it will be remembered, is not separated from the unsegmented mesoderm of the head, differ from those of the remaining somites in having this peculiar forward prolongation which, although it can be observed readily in transverse and sagittal and often in frontal sections, has never before been described. The obliquity of the sclerotomes of the first, and presumably the most primitive segments coupled with the well-known obliquity of the first one or two intersegmental clefts gives color to the suggestion that the segments of the chick are typically oblique rather than transverse structures and, consequently, that each vertebra arises from a single segment.

The lower myotomic groove deepens rapidly and, in embryos of twenty segments, appears on the posterior wall of the somites of the tenth segment. Neural crest cells, migrating downward, gather in the deep anterior part of this groove. The right and left aortae are now moving toward the median plane and consequently separate the notochord more widely from the entoderm.

The cutis plate of the tenth somite of embryos of twenty-five segments has nearly the same structure as that of the second somite of embryos of eighteen segments, except that, being composed of a greater number of cells, it more closely resembles a stratified columnar epithelium.

The deepening of the lower myotomic groove has now reduced the connection between the dermomyotome and the sclerotome to a slender stalk. This process accompanies the differentiation of the scelerotome into two conspicuous but not sharply defined regions. The medial portion of the sclerotome becomes less dense owing in part at least to its expansion into the space beside and below the notochord; its lateral part, on the other hand, becomes denser. The right and left aortae have united in this segment forming the median cylindrical aorta, which forces the 
notochordal processes of the sclerotome into a nearly horizontal position. The aortic process has been carried inward and is now a nearly vertical septum between the aorta and the posterior cardinal vein.

In embryos of thirty segments, the dermomyotome of the tenth somite is quite separated from the sclerotome and is inclined downward and laterally approximately at an angle of $45^{\circ}$ with the sagittal plane of the embryo. Its breadth ( 255 microns) is nearly twice its length (150 microns). The ventro-medial surface of the dermomyotome is strongly convex except at the upper and lower edges where it is barely concave. Its dorso-lateral surface is slightly convex, both at the edge and at the center, and the intermediate zone is flat or barely concave. The central convexity of both surfaces of the dermomyotome is due apparently to the expansion of the tissue of the dermatome as it becomes mesenchyma. A small central area of the dermatome is entirely converted into mesenchyma and a circular zone as broad as the dermomyotome is long and somewhat more than half its breadth is partly so. The lower edge of the dermomyotome rests upon the posterior cardinal vein and is partly separated from the ectoderm by a thin sheet of compact mesenchyma belonging to the parietal plate but its slight contact with the ectoderm forms a definite boundary which proves beyond doubt that the mesenchyma in the concavity of the muscle plate cannot have migrated from the parietal plate. The increased breadth of the dermomyotomes seems to be due to two factors-intrinsic growth and the addition of new material at its dorsal growing edge. The cavity of the segment is represented by small cavities in the upper and lower edges of the dermomyotome.

The sclerotome is fusing with the adjacent sclerotomes and its tissue is becoming vascularized.

Figure 17 represents a frontal section through the tenth somite of an embryo of forty segments. It is remarkably like figure 120, p. 205, of a somite of the rabbit in Minot's "Human Embryology." The dermomyotome, which in embryos of thirty segments was inclined approximately at an angle of $45^{\circ}$ with the median plane, is now nearly vertical. The plane of the section is slightly inclined 
upward laterally and, as the disintegration of the cutis plate has proceeded but slowly, the upper part of the area of partial disintegration is shown in the section. The spinal ganglion is now well defined and is quite surrounded by mesenchyma. The spinal nerve extends downward nearly into the section figured. The sclerotome is bounded anteriorly and posteriorly by the intersegmental vessels (I.A., I.V.), laterally by the muscle plate $(M$.$) , medially by the notochord (N)$, and at a higher level by the neural tube, ventrally by the aorta and the posterior cardinal vein. The sheet of sclerotomic tissue between the aorta and the notochord has become considerably thicker, and a similar but very thin sheet separates the notochord from the neural tube. The loose tissue surrounding the notochord, and extending as far laterally as the intersegmental arteries $(I . A$.), forms a continuous perichordal sheath in which no visible condensations occur. The intersegmental arteries mark the outer limit of the future vertebral centra and the body of each vertebra will form in this originally homogeneous perichordal sheath which was first described by Gegenbaur. No portion of this sheath can be assigned with accuracy to any particular somite or selerotome, for we have seen that the anterior ends of the sclerotomes of the second to the fifteenth segments extend far forward under the preceding sclerotomes. Laterally to the intersegmental arteries the sclerotomic tissue rapidly becomes denser except in the middle of the sclerotome where a thin vertical zone of loose tissue, the "intervertebral fissure," divides the denser tissue into distinct anterior and posterior portions which take the form of square columns. These two columns of dense selerotomic tissue are generally, but I believe wrongly, regarded as morphological entities. There is, however, some difference of opinion as to their exact meaning. Those who hold to Remak's theory of vertebral resegmentation as modified by Von Ebner, consider them to be the anterior and posterior halves of the right or left half of the "primitive vertebra." Others, however, who accept Schauinsland's theory (which, as was pointed out above, is closely related to Goette's theory) that there are two "primitive vertebrae" in each segment, regard each column of dense sclerotomic tissue as simply one-half of the anterior 
or the posterior vertebra of the segment. These columns are, I believe, nothing more than centers of growth which have been cut off by the lower myotomic groove from the zones of growth of the anterior and posterior edges of the dorsal lamella of the somite. They certainly contain (as Von Ebner pointed out in 1892, and as I have maintained elsewhere) the anlagen of a large number of structures. The anterior, however, differs largely from the posterior column, owing, I believe, to the intrusion of the spinal ganglion and nerve into it and the consequent interference with its development.

The cutis plate of each somite of the tenth segment of an embryo of forty-four segments (H. E. C. no. 98) has given rise to a large mass of loose dermal mesenchyma and to a wall-like peripheral zone of denser mesenchyma which extends from the zone of proliferation at the anterior, posterior, and dorsal edges of the myotome and from the remnant of the lower edges of the cutis plate to the ectoderm. The septum of denser mesenchyma is attached to the ectodermal thickening or ridge along the anterior, posterior, and lateral (or ventral) boundaries of the somite, and seems to draw the ectoderm toward the myotome, causing a deep invagination of the ectoderm. The existence of this invagination around three sides of the somites accounts for the greater conspicuousness of the somites of entire embryos of three or four days than of those of younger embryos.

The outer lamella of the rapidly growing upper edge of the dermomyotome is not affected by the disintegration of the cutis plate, for as Engert, has shown, this edge of the dermomyotome becomes enlarged, appearing in transverse sections like a pothook or a shepherd's crook, and is transformed bodily into myoblasts.

The sclerotomic tissue, both of the perichordal sheath and of the sclerotomic columns, is considerably denser than before. Sympathetic ganglia are now present in the tenth segment.

In embryos of forty-eight to fifty-two segments (H. E. C. nos. 478,483 , and 526) the dense peripheral portion of the dermal mesenchyma has become much less conspicuous except along the dorsal and the upper part of the anterior and posterior edges of 
the myotome. The corresponding ectodermal ridge, however, has been elevated, especially its vertical portions, into an acuminate septum-like structure which in one case projects medially from the bottom of the ectodermal invagination 50 microns, or more than one-third of the distance from the bottom of the ectodermal invagination to the myotome.

The cutaneous blood vessels pass to the skin through the gaps between the lower ends of the myotomes.

The nyotome is considerably thicker than before, and, except at its upper and lower edges, is now triangular in frontal section. Its outer surface is flat or slightly convex and its medial surface is now divided into two equal surfaces which, facing slightly forward and backward, meet in a large obtuse angle that varies in different levels from about $120^{\circ}$ to $160^{\circ}$. The myoblasts of the lateral part of the myotome are in a more advanced stage of development than those of the medial portion, and they seem to stretch from the antero-medial to the posterior medial surface of the myotome. The myoblasts of the medial part of the myotome are shorter and are more irregularly arranged than the more lateral myoblasts. Those in immediate contact with the medial surfaces near the medial angle of the myotome form an epithelioid layer.

The transverse diameter or breadth of the intervertebral fissure is considerably reduced owing to the encroachment of the medial angle of the myotome.

The axial mesenchyma is denser than in embryos of fortyfour segments, and there has now appeared an extensive midsegmental subnotochordal condensation which is continuous laterally with the dense anterior and posterior sclerotomic columns.

The presence of the large spinal nerve and the sympathetic ganglion in the anterior sclerotomic column interferes with the original continuity of the anterior column and therefore Froriep and Bardeen have conceived that the dense tissue of each segment forms a simple lyre-shaped mass extending from the median midsegmental point laterally, upward, and backward. Froriep calls this structure the primitive vertebral arch, and Bardeen names it the scleromere. Remak names its central portion the primitive vertebral centrum, and its lateral portions the verte- 
bral arches. Froriep shows that the primitive vertebral centrum soon extends around the notochord and differentiates into the perichordale Faserring and the cartilaginous hypochordale Spange. The former takes part in the formation of the intervertebral joint or in mammals forms the intervertebral disc - the latter is the intercentrum (Männich, '02) or the haemal arch (Schauinsland, '05). Froriep further shows that the vertebral centra are formed from the loose tissue of the perichordal sheath between the successive midsegmental condensations. I believe it will be found that in the chick, as in the pig, cartilage arises from relatively loose, not from dense mesenchyma, or that when it does arise in dense tissue it does so only after a previous loosening up of the dense tissue. This is certainly true of the centrum and intercentrum. We ought, I believe, to regard the scleromere as a composite structure, not as a morphological or structural unit. It is unwise, therefore, to try to homologize the sclerotomic columns or halves or the scleromere with the vertebra or with any of its elements.

\section{THE TWENTY-FIFTH SOMITE}

The twenty-fifth segment (fig. 13) at the time of its formation is in a more advanced state of development than the second or the tenth when they first appear, and it passes with great rapidity through the first steps of its later development. In an embryo of twenty-seven segments (H. E. C. no. 1520) each somite of this segment is already divided into the sclerotome and the dorsal lamella, and both myotomic grooves have appeared. The upper myotomic groove, however, is very shallow and is so indistinct that it is not readily seen. The lower groove entirely encircles the somite and neural crest cells are already moving down into its deep anterior end. The newly formed sclerotome has fused with the preceding and following sclerotomes, but not with the opposite one. It is continuous laterally with the mesenchyma of the nephrotome and through it with that of the lateral plate. The aorta, the posterior cardinal vein and the connecting interseg- 
mental vessels are present. The aorta lies directly beneath the somite, but it is almost in contact with the lateral plate. The posterior cardinal vein lies directly above the Wolffian duct which in turn lies in a groove between the lateral plate and the nephrotomic mesenchyma.

The twenty-fifth somite of each side in embryos of thirty-three segments (H. E. C. nos. 97 and 1587) is triangular. The aortae have moved together and have fused. The entire nephrotome with the posterior cardinal vein has moved toward the median plane, and consequently the sclerotome is now bounded ventrally by the aorta, the mesonephric tubules, the Wolffian duct, and the posterior cardinal vein. The dorsal surface of the somite, owing to the lateral inclination downward of the dorsal lamella, makes an angle of $45^{\circ}$ with the sagittal plane.

The lateral edge of the dorsal lamella has grown ventro-laterally some distance beyond the ectodermal ridge which formerly marked the lateral boundary of the somite and now is pushing into the dense mesenchyma of the Wolffian ridge. The myotome now underlies all of the dorsal lamella but a small area in the middle of its ventro-lateral edge. The sclerotome is definitely divided into a loose medial and a dense lateral part. The two sclerotomes of this segment have united in the median plane so that a nearly continuous sheet of sclerotomic tissue separates the aorta and the notochord. Neural crest cells continue to migrate into the spinal ganglion.

After the first phase of rapid development, changes in the structure of the twenty-fifth segment are less rapid. The dermomyotome of each of the twenty-fifth somites of an embryo of forty-four segments is essentially as far advanced as that of the second somite of an embryo of forty segments. There is, however, a striking difference between the two (compare fig. 16 with fig. 9). The ventral edge of the dermomyotome of the twenty-fifth somite contains a center of growth and extends downward until it comes in contact with the coelomic epithelium. This edge of the dermomyotome thus comes to lie medial to a large wedge-shaped process of the mesenchyma of the Wolffian ridge. This process extends upward between the dermomyotome and the ectoderm to 
the longitudinal ectodermal invagination which marks the former lateral boundary of the somite. The center of the cutis plate, comprising about one-third of the whole, is now entirely transformed into dermal mesenchyma, and the adjacent portion of the cutis plate, including perhaps another third, is partially transformed into mesenchyma. The dermal mesenchyma of this somite is quite dense. It extends from the myotome to the ectoderm and it also projects in the form of a thin sheet between the partly transformed area of the cutis plate and the ectoderm. Ventrally the dermal mesenchyma reaches nearly to the upper edge of the mesenchyma of the Wolffian ridge, from which, however, it is separated by a small space that intervenes between the ectodermal ridge and invagination that mark the former lateral boundary of the somite and of the dermomyotome. The presence of this gap between the mesenchyma of the cutis plate and that of the parietal plate makes it clear that the former does not arise from the latter but that the two mesenchyma masses arise separately. The later development of the myotomes of the trunk has been followed by Engert.

THE FORTY-FOURTH SOMITE

The history of the forty-fourth segment does not differ much from that of the twenty-fifth segment except that shortly after its differentiation into muscle, and dermal and axial connective tissue, it degenerates. In an embryo of forty-nine segments (H. E. C. no. 478) the core of each somite of this segment has fused with the lower part of its cortex and both the upper and the lower myotomic grooves are present. The upper groove is more distinct than in the twenty-fifth segment, and the lower groove is deeper on the lateral than on the medial surface of each somite.

The dermomyotomes of the forty-fourth segment of an embryo of fifty-one segments (H. E. C. no. 526, 5 days), are complete, but are not cut off from the sclerotomes. The sclerotomes of this segment have fused with the large mass of hypomerous mesenchyma and with the adjacent sclerotomes. 
In an embryo of fifty-two segments (H. E. C. no. 344, 5 days 16 hours) which, however, is considerably older than the one of fifty-one segments, the mesenchymal mass (fig. 18, $S$ ) formed by the fusion of the sclerotomes with the hypomerous mesenchyma almost surrounds the dermomyotomes of the forty-fourth segment and meets above the neural tube. The dermomyotome is still intact notwithstanding the conversion of the central part of the cutis plate into mesenchyma. The lower edge of the dermomyotome and that of the myotome are somew that enlarged. The upper edges of both are thin.

In transverse sections we find, in the upper part of the sections, four layers of tissue between the ectoderm and the notochord namely, a layer of mesenchyma (fig. 18, $S$ ) which extends upward between the dermatome $(D)$ and the ectoderm nearly or quite to the top of the dermomyotome; a second layer of mesenchyma representing the central part of the cutis plate $(D)$; the myotome $(M)$; and a thick layer of sclerotomic tissue which is divided into a lateral zone, of dense and a medial zone of looser tissue.

In a somewhat older embryo (H.E. C. no. 485,5 days, 18 hours) the dermal mesenchyma has fused with that between the dermomyotome and the ectoderm, and the resulting mass of tissue is supplied with a rich plexus of blood vessels. The lower edge of the myotome bears a small epithelioid cap which represents a much reduced ventral zone of growth. The upper edge of the myotome bears a somewhat rounded zone of growth.

\section{SUMMARY AND CONCLUSIONS}

Although the somites have the same fundamental structure in all parts of the body, they differ greatly in many respects.

The first somite at its origin is the smallest of the entire series, with the possible exception of some of the degenerate caudal somites, and each succeeding somite of the neck and trunk is larger than the preceding somite.

Every somite, owing to the rapid growth of the anterior part of the embryo, is larger at any one time than any of the following somites. 
A given somite does not recapitulate the development of each or any preceding somite; on the contrary, each succeeding somite is in a more advanced structural condition at the time of its formation than the preceding somites.

Each somite divides first into the primary sclerotome, formed by the fusion of the core with the floor and the lower part of the walls of the somite, and the dorsal lamella which consists of the roof or dorsal wall of the somite and a bordering zone of growth developed in the upper part of the medial, anterior, and posterior walls and, in the somites of the trunk, of the lateral wall also.

The dorsal lamella gives rise to the dermomyotome and also, I believe, to two large dense masses of sclerotomic mesenchyma, the anterior and posterior "halves" of the sclerotome, or, as I perfer to call them, the anterior and posterior sclerotomic columns.

The myotome, or muscle plate, is formed in a large measure, particularly in the occipital and cervical regions, by proliferation from the medial edge of the dorsal lamella but in the trunk and to a less degree in the tail, the lateral edge of the dorsal lamella contributes to its growth.

The anterior and posterior edges of the dorsal lamella contribute but slightly to the myotome. They produce, however, a large amount of mesenchyma which is added to the primary sclerotome and which forms the dense anterior and posterior columns of the secondary sclerotome.

The sclerotomic columns, which are usually regarded as morphological units that represent one or more elements of a primary or secondary vertebra, are actually composite structures in which the several morphological elements cannot be distinguished.

The perichordal sheath, in which the centra and intercentra arise, is formed by the fusion of the notochordal processes of the primary sclerotomes. The notochordal processes of the first fourteen pairs of sclerotomes, exclusive of those of the first segment, grow far forward under the preceding segments; consequently parts of the perichordal sheath can be only vaguely assigned to particular segments. Each centrum arises in an intersegmental part of the perichordal sheath and is formed from loose tissue; each intercentrum, on the contrary, arises in a midsegmen- 
tal condensation. The ribs in the same way arise in the dense tissue of the posterior selerotomic columns. There is, therefore, much reason to believe that in the chick cartilage arises from relatively loose as well as from dense tissue and also that dense tissue always becomes somewhat looser before cartilage forms in it. I have maintained in a former paper that cartilage arises in this manner in the pig.

There is a possibility that the forward growth of the lower part of the sclerotome is a typical condition in vertebrates and, consequently that the vertebrae are truly segmental structures.

Paterson showed that the dorsal and ventral edges of the dermomyotomes of the trunk grow rapidly upward and downward respectively into the membrana reuniens superior and inferior. They are ultimately converted, as Engert shows, en masse into myoblasts and form the thick dorsal and ventral edges of the myotome.

Rabl was right in asserting that the cutis plate in the chick gives rise to dermal connective tissue, and I question the correctness of Bardeen's theory that the cutis plate in the pig produces only myoblasts.

Finally, I wish to call attention to the circumstance that the anterior cardinal vein arises in part from a branch of the aorta that is comparable to the first intersegmental artery. 


\section{BIBLIOGRAPHY}

BARDEEN, C. R. 1900 The development $0^{*}$ the musculature of the body wall in the pig. Johns Hopkins Hospital Reports, vol. 9, pp. 367-399, 10 pls. 1905 The development of the thoracic vertebrae in man. Am. Jour. Anat., vol. 4, pp. 163-174, 7 pls.

Bardeen, C. R., and Lewis, W. H. 1901 Development of the limbs, body-wall and back in man. Am. Jour. Anat., vol. 1, pp. 1-35, pls. 1-9.

Bonnet, R. 1884 Beiträge zur Embryologie der Wiederkäuer gewonnen am Schafei. I Arch. f. Anat. u. Physiol., Anat., Abth., pp. 170-230, pls. 9-11.

1889 II Ibid., pp. 1-106, pls. 1-6.

Chiarugi, G. 1889 Lo sviluppo dei nervi vago, accessorio, ipoglosso e primi cervicali nei sauropsidi e nei mammiferi. Atti. Soc. Tosc. Sc. Nat., Pisa, vol. 10, pp. 149-24., pls. 11-12.

Conning, H. K. 1891 Ueber die sog. Neugliederung der Wirbelsäule und über das Schicksal der Urwirbelhöhle bei Reptilien. Morphol. Jahrb., vol. 17 , pp. $611-622$, pl. 30 .

Dexter, S. 1891 The somites and the coelome in the chick. Anat. Anz., vol. 6 , pp. 284- $\angle 89$, 4 figs.

Von Ernar, V. 1888 Urwirbel und Neugliederung der Wirbelsäule. Sitzb. d. k. Akad. d. Wiss., Wien, 97, Abth. 3, pp. 194-206, pls. 1-2.

1892 Ueber die Beziehungen der Wirbel zu den Urwirbel. Sitzb. d. k. Akad. d. Wiss., Wien, 101, Abth. 3, pp. 235-260, pl. 1.

Engert, H. 1900 Die Entwicklung der ventralen Rumpfmuskulatur bei Vögeln. Morphol. Jahrb. 29, pp. 169-186, pls. 8-10.

Evans, H. M. 1909 On the earliest bloodvessels in the anterior limb buds of birds and their relation to the primary subelavian artery. Am. Jour. Anat., vol. 9, pp. 281-319, 20 figs.

1909 On the development of the aortae, cardinal and umbilical veins and other blood vessels of vertebrate embryos from capillaries. Anat. Rec., vol. 3, pp. 498-518, 21 figs.

Fisches, A. 1895 Zur Entwickelung der ventralen Rumpf- und Extremitätenmuskulatur der Vögel und Säugetiere. Morphol. Jahrb., vol. 23, pp. $544-561$, pl. 28 .

Fronies, A. 1883 Zur Entwickelungsgeschichte der Wirbelsäule, insbesondere des Atlas und Epistrophius und der Occipital Region. Arch. f. Anat. u. Physiol., Anat. Abth., pp. 177-23 i, pls. 7-9.

Gegenbaur, C. 1862 Untersuchungen zur vergleichenden Anatomie der Wirbelsüule bei Amphibien und Reptilien. Leipzig, 72 pp., 4 pls.

GomTre, A. 1875 Die Entwickelungsgeschichte der Unke. Leipzig, 965 pp. Atlas. 1896 Ueber den Wirbelbau bei den Reptilien und einigen anderen Wirbeltieren. Zeitschr. f. wiss. Zool., vol. 62, pp. 343-394, pls. 15-17. 
HuLd, H. 1909 Die Entwicklung des Nervengewebes bei den Wirbeltieren. Leipzig, 378 pp., 53 pls., 275 figs.

Hus, W. 1868 Untersuchungen über die erste Anlage des Wirbeltierleibes. Die erste Entwickelung des Hühnchens im Ei. Leipzig, 16+237 pp., 12 pls.

Hubbard, M. E. 1908 Some experiments on the order of suecession of the somites of the chick. Am. Nat., vol. 42, pp. 466-471, 2 figs.

KöLunkwr, A. 1879 Entwickelungsgeschichte des Menschen und der höheren Ticre. 2 ed., Leipzig.

Kollmann., J. 1891 Die Rumpfsegmente menschlicher Embryonen von 13 bis 35 Urwirbeln. Arch. f. Anat. u. Physiol., Anat. Abth., pp. 39-88, pls. $3-5$.

l,ILlie, F. R. 1908 The development of the chick. New York, 472 pp., 250 figs.

MäNNer, H. 1899 Beiträge zur Entwickelungsgeschichte der Wirbelsäule bei Reptilien. Zeitschr. f. wiss. Zool., vol, 66, pp. 43-68, pls. 4-7.

MaNNICH, H. 1902 Beiträge zur Fntwickelung der Wirbelsäule von Eudyptes chrysocome I. D., Univ. Leipzig, 46 pp., 1 pl.

Mäurelk, F. 1904 Entwickelung des Muskelsystems und electrischen Organe. Hertwig's Handbuch der vergl. u. exper. Entwiekelungslehre der Wirbeltiere, Bd. 3, Teil 1, 1-80, 41 figs.

Minot, C. S. 1892 Human embryology. New York, 815 pp.

Paterson, A. M. 1888 On the fate of the muscle-plate and the development of the spinal nerves and limb plexuses in birds and mammals. Quart. Journ. Microscop. Sci., vol. 28, pp. 109-129, pls. 7-8.

PAtTerson, T. J. 1907 The order of appearance of the anterior somites of the chick. Biol. Bull., vol. 13, pp. 121-133.

RaBl, C. 1888 Ueber dio Differenzierung des Mesoderms. Verh. d. Anat. Ges., Würzburg, vol, 2, pp. 140-146, 8 figs.

1889 Theorie des Mesoderms, I. Morphol. Jahrb., vol. 15, pp. 113252 , pls. $7-10$.

R̈мак, R. 1855 Untersuchưngen über die lintwicklung der Wirbeltiere. Berlin, $37+194$ pp., 12 pls.

Schaunsland, H. 1900 H. Weitere Beiträge zur Entwicklungsgeschichte der Hatteria. Arch. f. mikr. Anat., vol. 56, pp. 747-867, pls. 32-31. 1905 Die Entwickelung der Wirbelsäule nebst Rippen und Brustbein. Hertwig's Handbuch d. vergl. u. exper. Entwickelungslehre der Wirbeltiere, Bd. 3, Teil 2, pp. 339-572, 157 figs.

Wirxiams, L. W. 1908 The later development of the notochord in mamrals. Amer. Jour. Anat., vol. 8, pp. 251-284, 20 figs. 


\section{EXPLANATION OF FIGURES}

All figures are from series in the Harvard Embryological Collection. All figures except the text figure, are of the same magnification, 280 diameters.

Figures 1 to 9 represent transverse sections through the middle of one somite of the second segment of chick embryos.

1 From an embryo of two segments. Series 627, section 107.

2 From an embryo of three segments. Series 629 , section 100.

3 From an embryo of six segments. Series 632, section 120.

4 From an embryo of nine segments. Series 645 , section 149.

5 From an embryo of twelve segments. Series 1449, section 183.

6 From an embryo of fifteen segments. Series 1460, section 163.

7 From an embryo of eighteen segments. Series 1466, section 170 .

8 From an embryo of twenty-five segments. Series 89, section 144.

9 From an embryo of forty segments. Series 100 , section 150 .

Figures 10 to 15 represent similar sections through one of the somites of the last segment of embryos of different ages.

10 From an embryo of five segments. Series 632, section 141.

11 From an embryo of ten segments. Series 42 , section 257.

12 From an embryo of fifteen segments. Series 1460, section 314.

13 From an embryo of twenty-five segments. Series 89, section 408 .

14 From an embryo of thirty segments. Series 95 , section 395.

15 From an embryo of forty-four segments. Series 98, section 287.

16 Somewhat oblique transverse section of one dermomyotome of the twentysixth segment of an embryo of forty-four segments. Series 98 , section 257 .

17 Frontal section through the left somite of the tenth segment of an embryo of forty segments. Series 100 , section 50 .

18 Transverse section of one dermomyotome of the forty-fourth segment of an embryo of fifty-two segments (5 days, 16 hours). Series 344, section 228.

A Aorta.

C Coelom.

$C^{1}$ Remnant of the cavity of the somite.

C. A Anterior cardinal vein.

C. $P$ Posterior cardinal vein.

$D$ Dermatome.

D. $M$ Dermomyotome.

$E$ Ectoderm.

$G$ Entoderm.

$G$. L Lower myotomic groove.

$G$ U. U Upper myotomic groove.

I. A Intersegmental artery.
I. $V$ Intersegmental vein.

$M$ Myotome.

M. P Myocardial process of the lateral plate.

$N$ Notochord.

$N$. C Neural crest.

P. A Aortic process of sclerotome.

$P . N$ Notochordal process of sclerotome.

$S$ Hypomerous mesenchyma.

$\checkmark$ Vascular cells. 

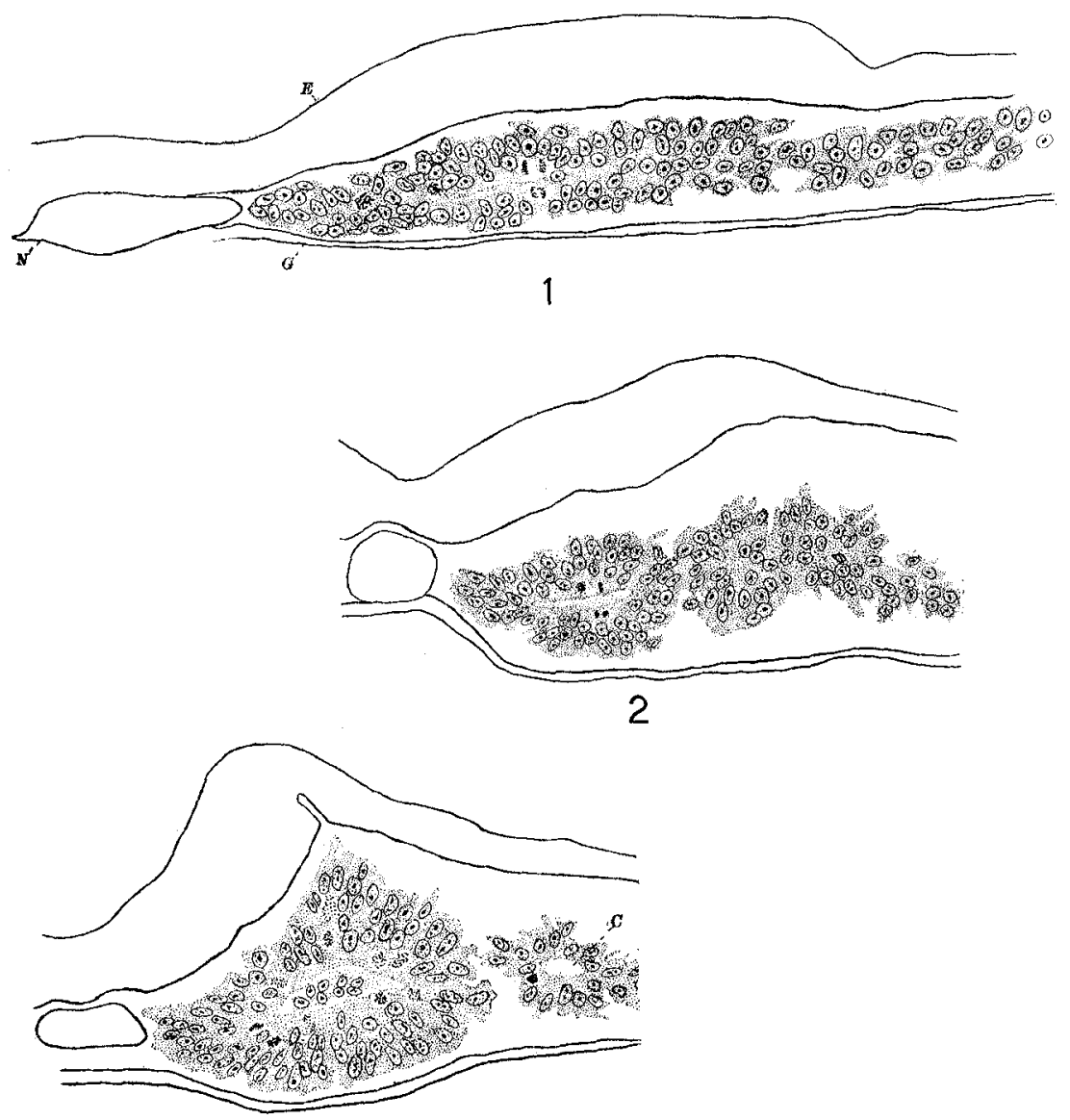

3

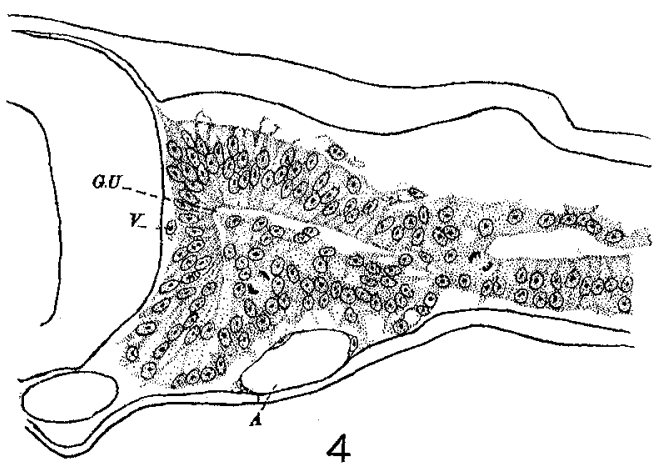




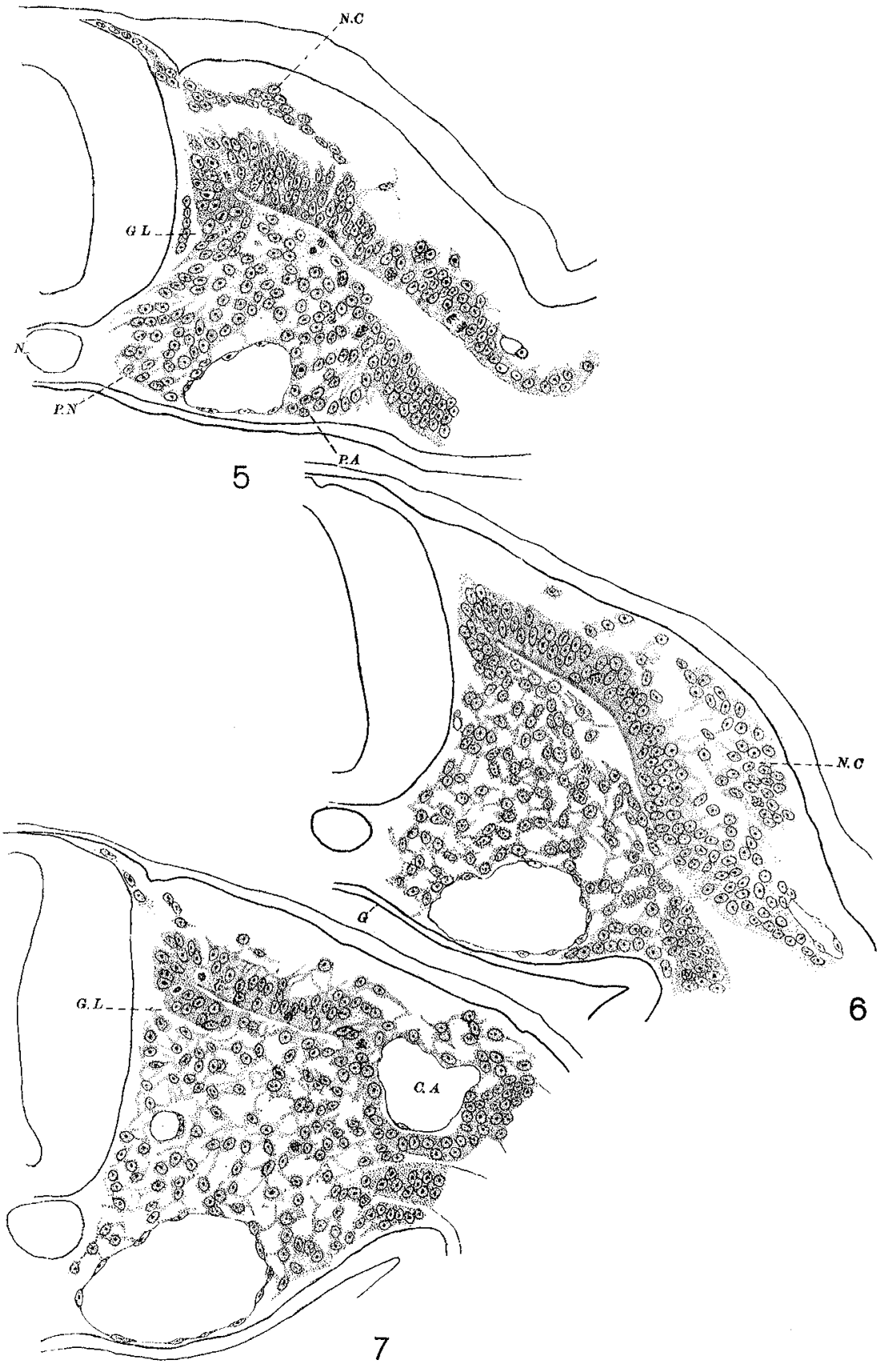




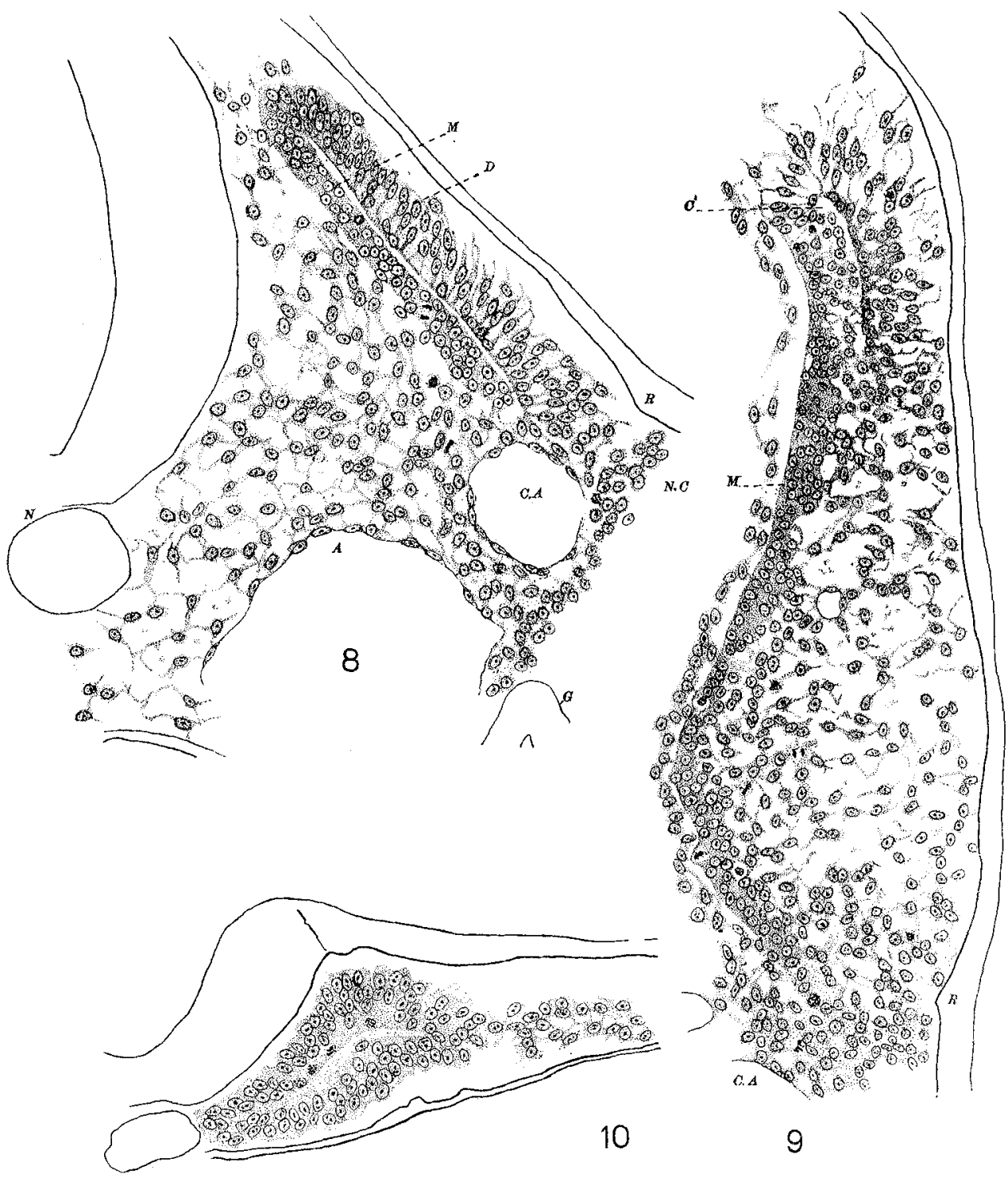

THE AMERICAN JOURNAL ON ANATOMX, VOL. 11, NO. 1. 

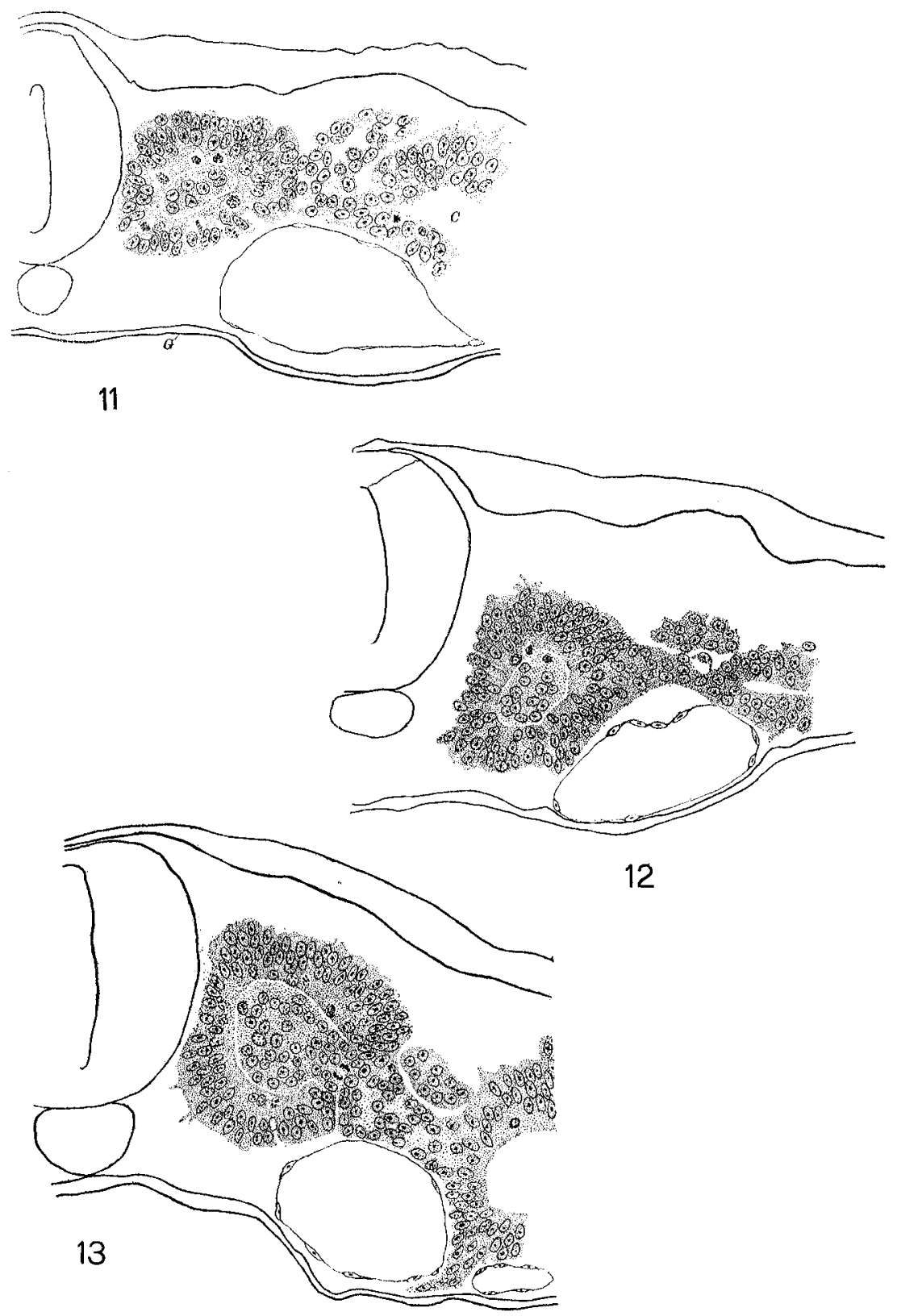


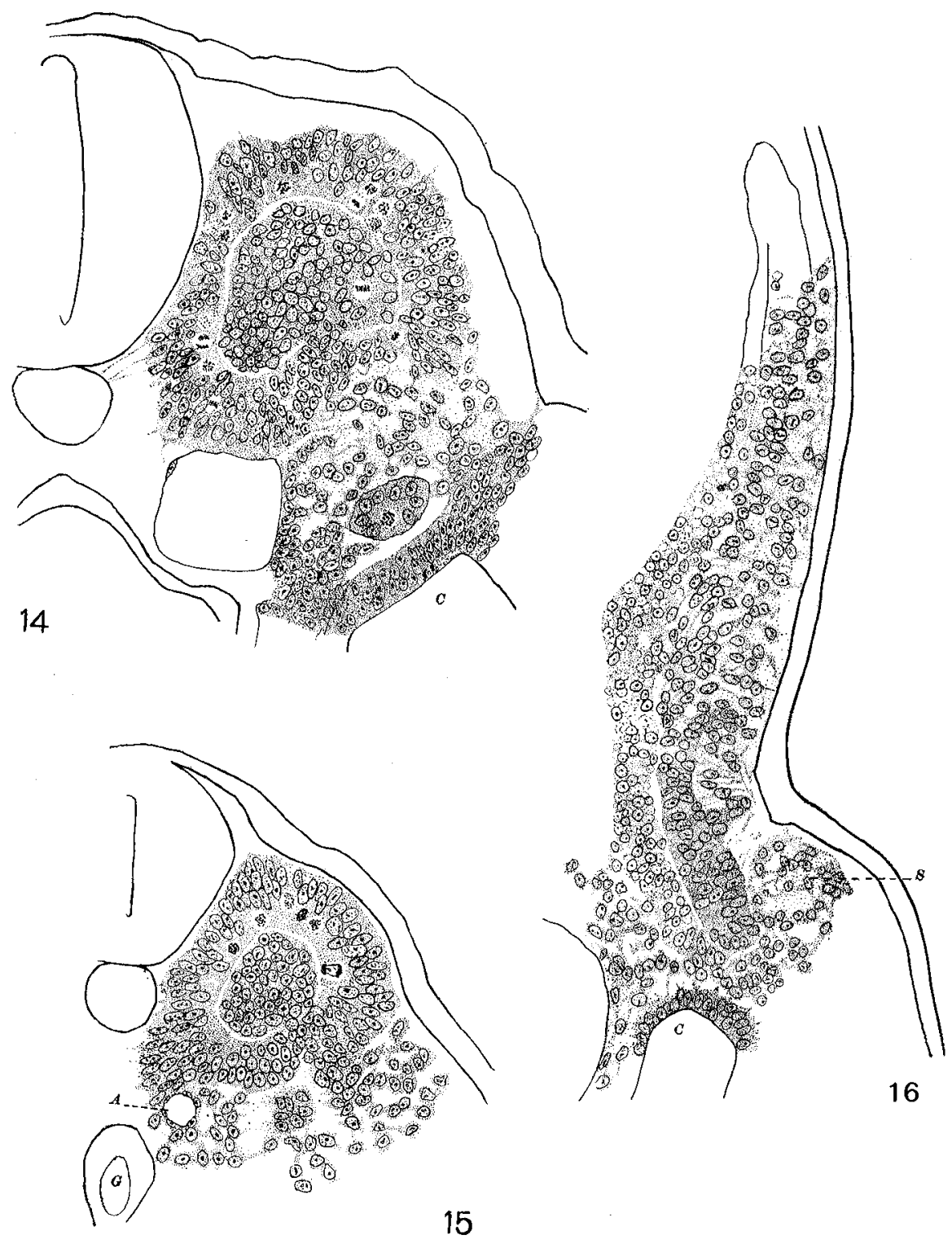



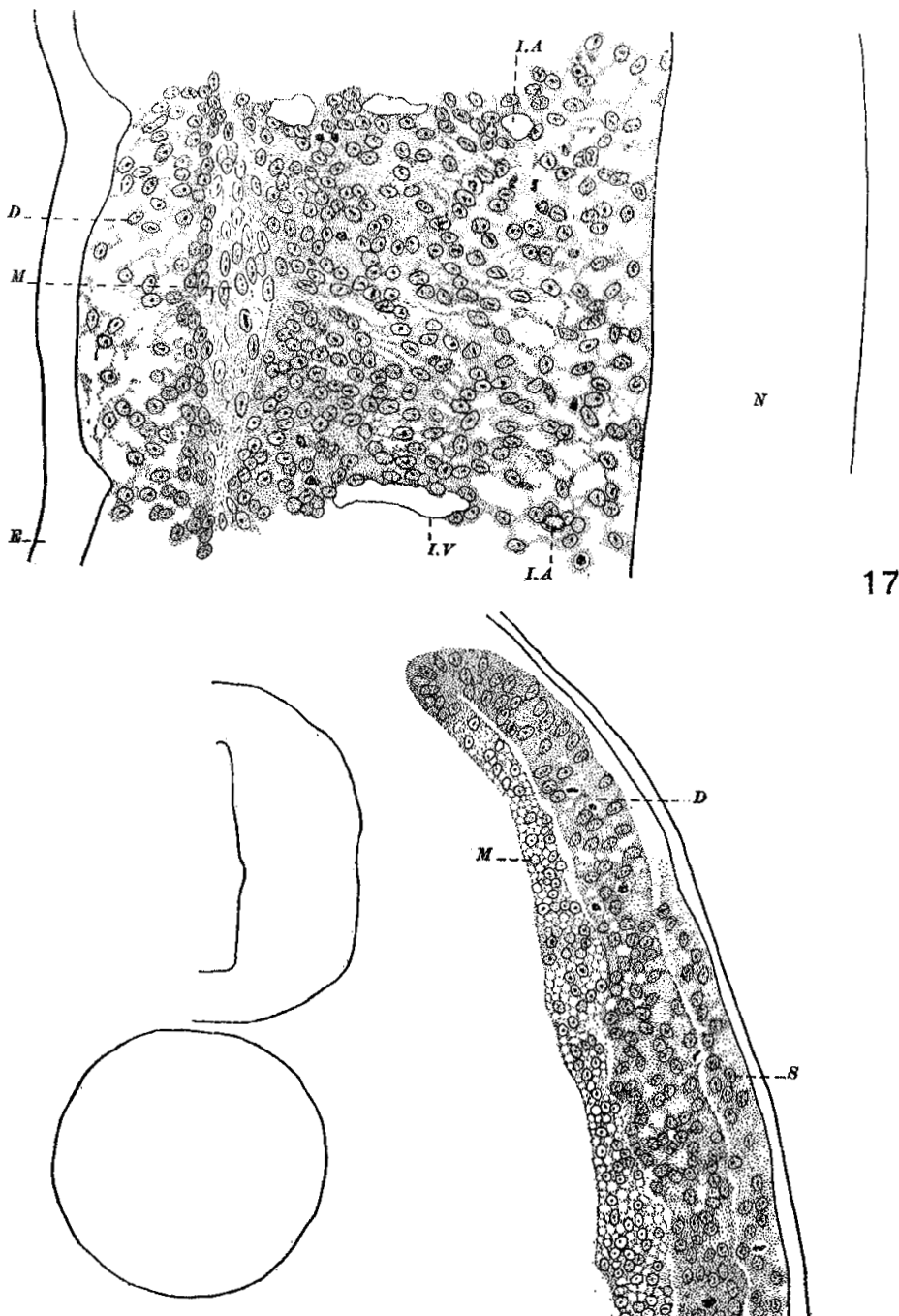

18

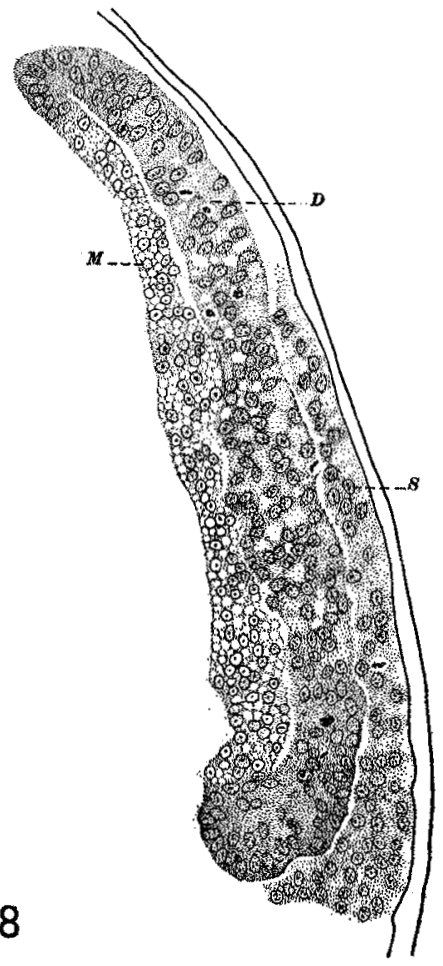

